\title{
An Update On The Data About The Late Neolithic And Eneolithic In Friuli
}

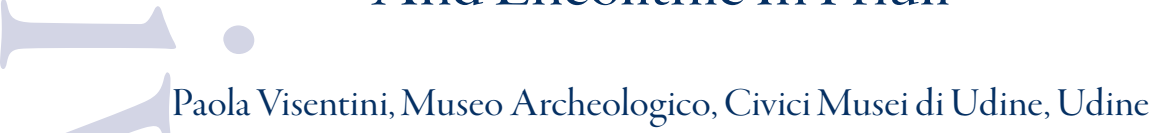

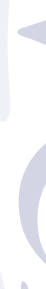

V zadnjih letih so nam ponovno preučevanje starih najdb, nekaj slučajnih odkritij in nedavna izkopavanja omogočili prenovljen vpogled v najmlajše faze neolitika in eneolitika v Furlaniji. Obsežni podatki, ki so nam na voljo, nam za enkrat še ne omogočajo, da bi predstavili celovito sliko, vendar prikazujejo obsežno območje poselitve, ki ga v poznem neolitiku zaznamujejo padanski kulturni vplivi, medtem ko se v času eneolitika pojavijo značilni znaki povezav s čez alpskim in še posebej z balkanskim svetom.

Ključne besede: pozni neolitik, eneolitik, naselbinska tipologija, keramika, industrija kamnitih odbitkovnih orodij, industrija glajenih orodij, kovinske najdbe, poselitev, kulturni vplivi

In the last years, the re-examination of old finds, some casual discoveries and recent excavation works allowed us to update our knowledge on the latest phases of the Neolithic and Eneolithic in Friuli. The increasing data at our disposal do not allow to present an organic picture yet, but it depicts a vast occupation area characterised during the Late Neolithic by a Padan cultural influence, whilst during the Eneolithic significant signs of connections with the transalpine and especially the Balkan worlds have emerged.

Keywords: Late Neolithic, Eneolithic, settlement typologies, pottery, chipped lithic industry, polished lithic industry, metal artefacts, occupation, cultural influences

$\mathrm{n}$ the last years, the re-examination of old finds, some casual discoveries and recent excavation works allowed us to update our knowledge on the latest phases of the Neolithic and Eneolithic in Friuli (Tasca and Visentini 2010; Borgna et al. 2011; Visentini et al. 2015; Visentini 2018). The distribution of the finds demonstrate that funerary evidences are almost completely absent while settlements were limited, for now, to the high plain and piedmont areas, even though the numerous finds discovered out of context had a much wider diffusion on the territory.

At present, the data on the Late Neolithic environmental and palaeoeconomical aspects (Micheli in press) are being studied, whilst there are data available for the last phases of the Eneolithic from the fortified site at Meduno-Sach di Sotto, located in the north-western part of the region (Visentini et al. 2015).

\section{The Last Phases Of The Neolithic}

Overall, the region has presented many evidences attributable to the last phases of the Neolithic, but they mainly are finds with scarce lithic and/or ceramic materials attributable to that period and usually not coming from stratigraphic excavations, as is the case of Molin Nuovo (Fragiacomo and Pessina 1995) and Gramogliano (Bastiani et al. 1997) in the province of Udine, and San Tomé di Dardago in the province of Pordenone (Pettarin et al. 1997). As for Trieste's 


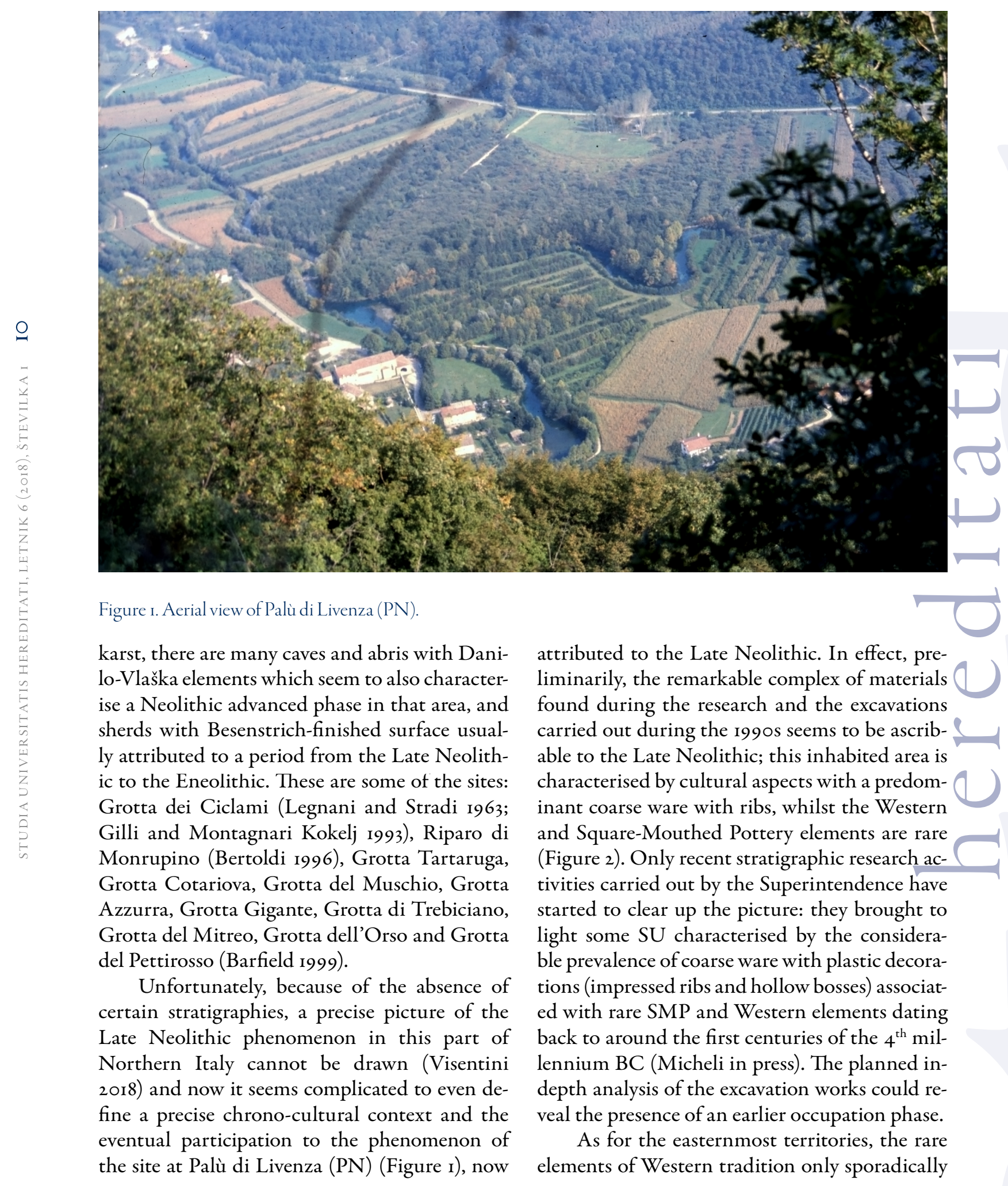



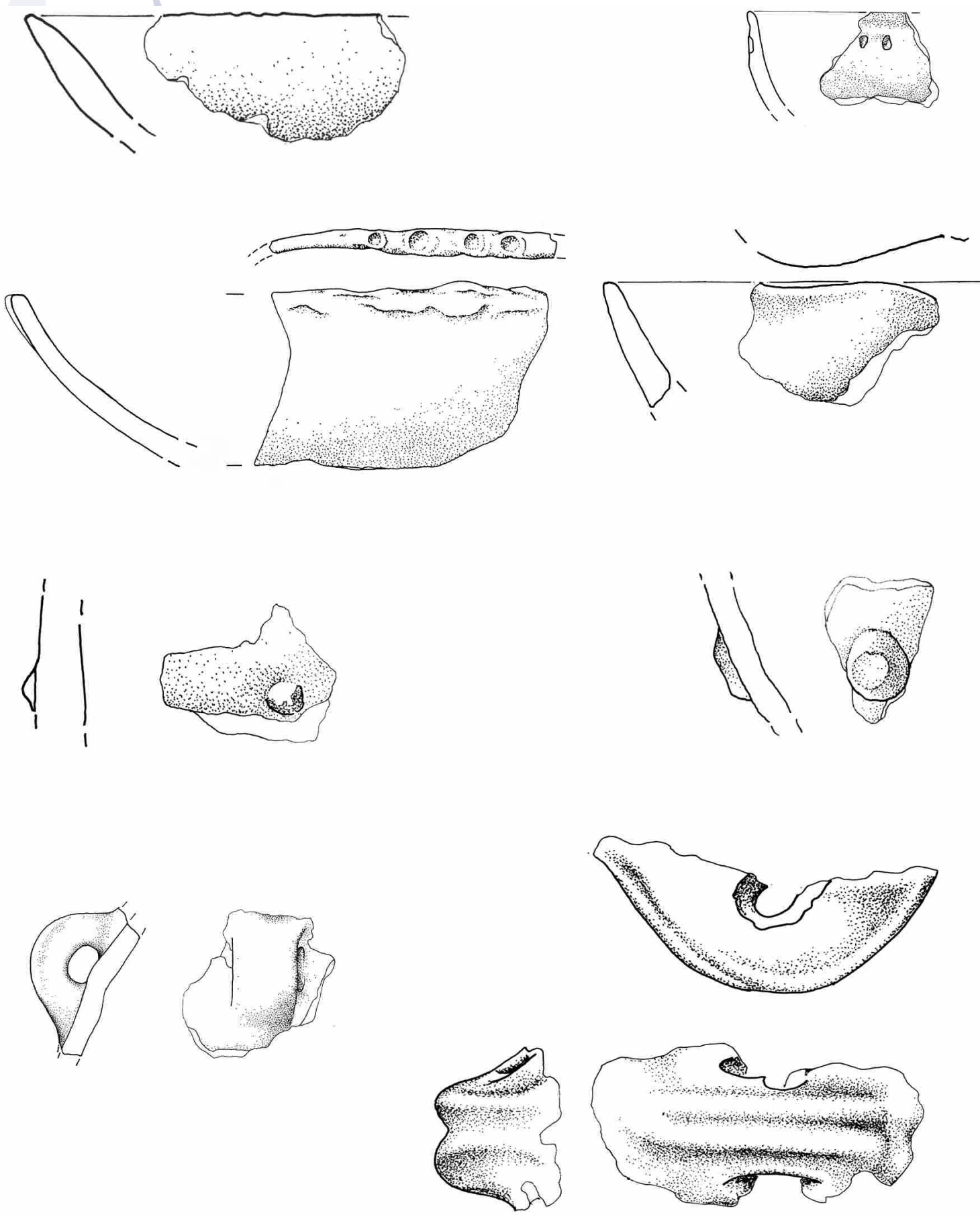

Figure 2. Palù di Livenza (PN). Pottery from SU 6 (after Visentini 2018). 


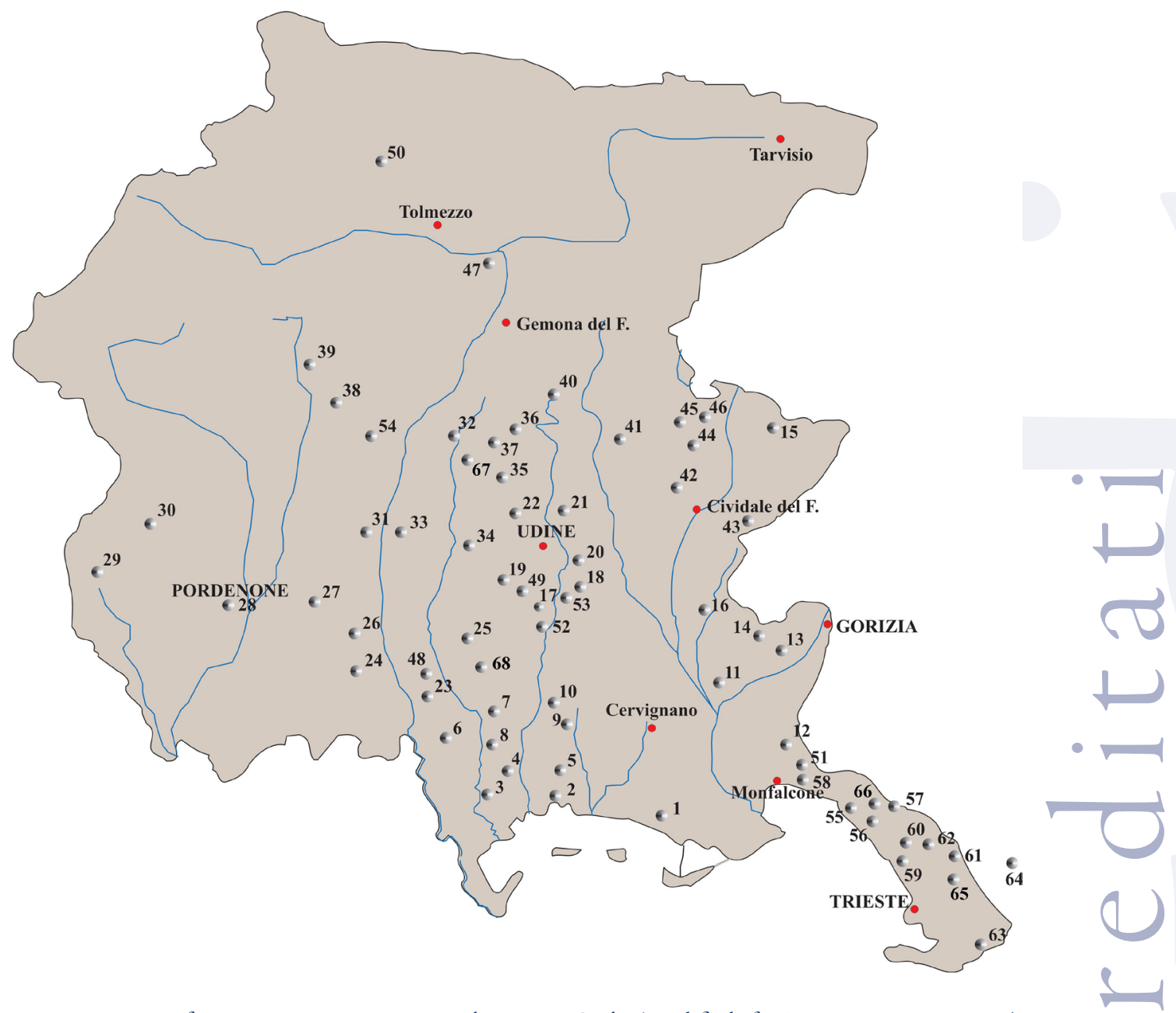

Figure 3. Location map of main copper age sites in Friuli Venezia Giulia (modified after Tasca \& Visentini 2010): I. Aquileia e Monastero (UD), 2. Marano Lagunare (UD), 3. Piancada (UD), 4. Muzzana del Turgnano (UD), 5. Carlino (UD), 6. Teor (UD), 7. Torsa (UD), 8. Pocenia (UD), 9. Porpetto (UD), ro. Castions di Strada (UD), ir. Medea (GO), I2. Monte Brestovez (GO), 13. San Lorenzo Isontino (GO), I4. Capriva (GO), 15. Monte Quarin (UD), 16. Gramogliano (UD), 17. Pavia di Udine, 18. Pozzuolo del Friuli (UD), 19. Carpeneto (UD), 20. Baldasseria, Pradamano (UD), 21. Molin Nuovo (UD), 22. Martignacco (UD), 23. Roveredo di Varmo (UD), 24. San Vito al Tagliamento (PN), 25. Venchiaredo (UD), 26. Sedulis e Cjastelar di San Giovanni di Casarsa (PN), 27. Zoppola (PN), 28. Pordenone, 29. Palu di Livenza (PN), 30. San Tome di Dardago (PN), 31. Gradisca di Spilimbergo, 32. San Daniele del Friuli (UD), 33. Sant'Odorico (UD), 34. Mereto di Tomba (UD), 35. Fagagna (UD), 36. Colloredo di Montealbano (UD), 37. S. Eliseo di Caporiacco (UD), 38. Palude di Sequals (PN), 39. Meduno (PN), 40. Tarcento (UD), 4r. Ciondar des Paganis (UD), 42. Foran di Landri (UD), 43. Grotta di Cladrecis (UD), 44. San Pietro al Natisone e Ponte San Quirino (UD), 45. Velika Jama (UD), 46. Gabrovizza (UD), 47. Colle Mazeit, Verzegnis (UD), 48. Rividischia (UD), 49. Sammardenchia (UD), 50. Muina, Ovaro (UD), 51. Castellazzo di Dorbedo (GO), 52. Nogaredo al Torre (UD), 53. Buttrio (UD), 54 . Anaret e Borgo Ampiano (PN), 55. Grotta dell'Edera, Caterina e Azzurra (TS), 56. Grotta del Pettirosso e del Mitreo (TS), 57. Grotta dell'Ansa (TS), 58, Grotta Teresiana (TS), 59. Grotta della Tartaruga (TS), 60. Grotta degli Zingari e Gigante (TS), 6r. Grotta Ciclami, Lonza e Riparo di Monrupino (TS), 62. Grotta Cotariova e dell'orso (TS), 63. Grotta delle Gallerie (TS), 64. Grotte di San Canziano (Slovenia), 65. Abisso di Trebiciano (TS), 66. Grotta del Muschio (TS), 67. Rive d'Arcano (UD), 68. Sterpo di Bertiolo (UD). 
ly plastic decorations. There are bowls with impressed rims, impressed mouth, conical bosses and hollow bosses right under the rim, and jars, non-articulated and extremely deep forms decorated with parallel series of impressed ribs, impressed ribs right under the rim and impressed ribs combined with hollow bosses. There are few four-spouted vessels and the elements of Western tradition are rare. Incised decorations are scarce if not completely absent.

As for the lithic industry, the provision systems, especially at Palù di Livenza, show the prevalence of raw materials coming from the province of Belluno and the Tagliamento's valleys, whilst only $40 \%$ of flint comes from the $\mathrm{Pi}$ attaforma Veneta (Dal Santo 2003). The technological aspects remained almost unvaried as compared to those highlighted in the third SMP style, with a variant constituted by the rise in the laminar production probably due to the connections with the Western world, which have been observed also in the pottery production (Bianchin Citton et al. in press). Probably because of the interest in new raw materials, the retouched artefacts are numerically scarce: some contexts documented the presence of elements ascribable to the SMP world, such as the tanged arrowheads and shoulders, or to the Western world, such as the transversal tranchets.

\section{Settlement Aspects, Funerary Evidences And Out-Of-Context Finds Attributable To The Eneolithic}

Evidences referring to the Eneolithic are much more considerable (Figure 3). Two pits containing pottery artefacts found in the high plain of the province of Udine could be attributed to the settlement aspects of its ancient phase. According to the typological comparison between materials, the most ancient pit seems to be the one found in the area surrounding the burial mound at $S$. Odorico di Flaibano (UD). Deep bowls with distinct rims have been compared with those found in the Ljubljana Marshes, at Maharski prekop, a site dating back to the first half of the IV millennium BC. The pit at Carpeneto, near Pozzu- olo del Friuli, not far from Udine, probably dates back to a slightly later period, between the mid$4^{\text {th }}$ and mid- $3^{\text {rd }}$ millennia BC. It was surveyed by the Superintendence in 2005. The sherd of a vessel with sinuous profile and vertical tunnel handle, and two rim's sherds, one probably belonging to a shallow bowl while the other to a bowl with narrow neck, can be compared to the finds from Hočevarica and Maharski prekop, in the Ljubljana Marshes, and an artefact found at Podmol, in the Slovenian karst (Borgna et al. 201I).

At S. Odorico di Flaibano, the remains of two Eneolithic huts have been found (Figure 4). The most ancient hut has an elliptical plan and it is approximately N-S oriented. It is delimited by a row of postholes, which is double on the North side, and it presents a line of six posts, probably used to bear the weight of the ca. 13 x $5 \mathrm{~m}$ roof. From a stratigraphic point of view, the other structure, delimited by a ditch, seems to be partially overlapping the first one. It has a $S$-W oriented and 9 × $6 \mathrm{~m}$ trapezoidal plan. The materials collected during the excavation works mostly come from the most recent structure: sherds of walls decorated with bosses, polished and fingertipped ribs, or transversal-notched impressions, tongue-like handles, sherds of bowls' rims, among which there is a bowl with inward-curved walls and a tube-shaped handle that reaches the rim. The common elements have been identified in Eneolithic sites in Austria and Slovenia, namely the Late Beaker Culture site of Oggau-Wipfing (Neugebauer and Neugebauer-Maresch 200r), and the inhabited areas of the Ljubljana Marshes ascribable to the Parte and Založnica's Somogyvár-Vinkovci facies (Vitri et al. 2012).

The biggest number of data has been collected in the settlement of Meduno-Sach di Sotto, located on the high plain in the province of Pordenone, between 292 and $297 \mathrm{~m}$ a.s.l., on a river terrace at the confluence of the Meduna and Rugo torrents. The settlement area is delimited east, west and south by a steep slope that reaches the watercourses. Northwards the rolling plain ends with a rectilinear embankment preserved for is in length and delimit- 


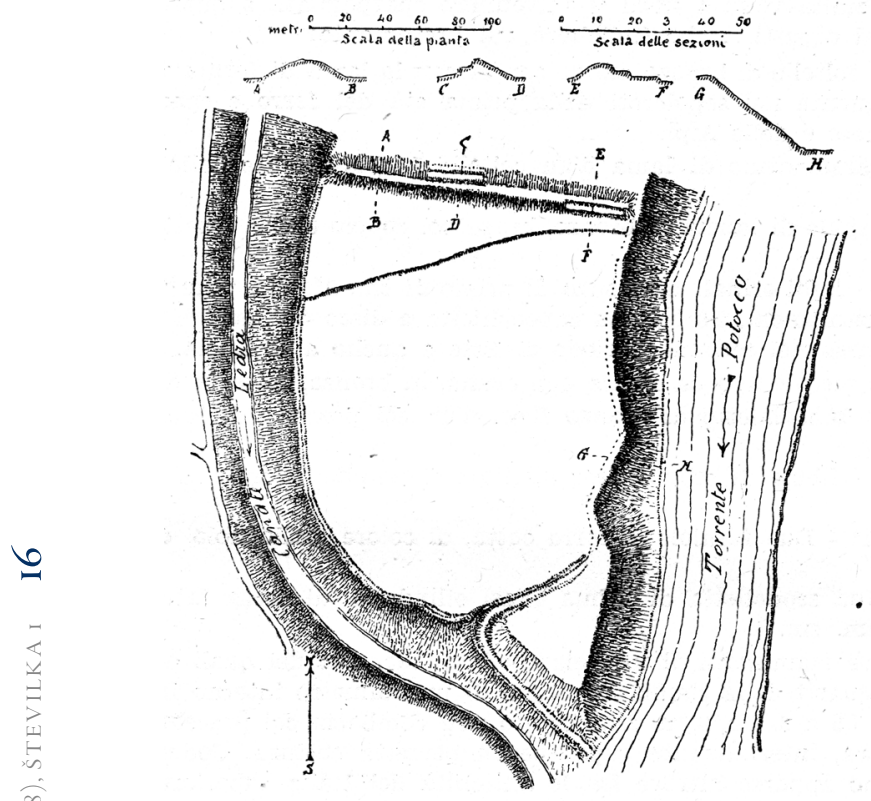

Figure 7. Survey map of Rive d'Arcano (UD) (after Quarina 1943).

ed by a ditch on its outer side (Visentini et al. 2015) (Figures 5 and 6). This type of settlement was already known in Friuli since the first years of the $20^{\text {th }}$ century, with some typological variants in two towns in the province of Udine: Rive d'Arcano (Figure 7), near San Daniele del Friuli, where northwards of the morainal promontory there is a rectilinear embankment, and Ponte San Quirino, near Cividale (Figure 8), that is also the originating site of the Eneolithic lithic industry (Gerdol and Stacul 1978, 70-80). Conversely to those two sites, the village of Meduno was not surveyed by Lodovico Quarina who, in the 1930s, was inspired by the research works of Giovanni Battista De Gasperi (Marinelli 1922) and, most of all, Achille Tellini (Tellini 1900), and described many of those emerging protohistoric structures. At that time the embankment was probably clearly visible, as it was only interrupted by one rural road, just like now. But given the similarity between the two above-mentioned settlements, Meduno-Sach di Sotto could be included in the category Quarina named "Castellieri (hillforts) near watercourses" (category C) (Quarina 1943). In truth, now we know that it is

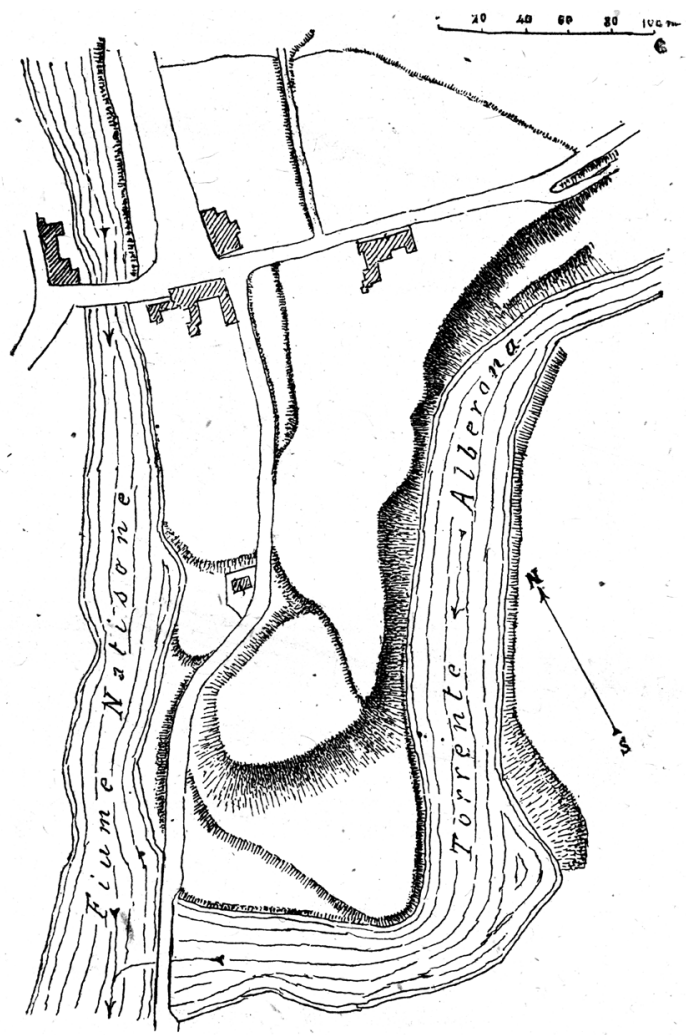

Figure 8. Survey map of Ponte San Quirino (UD) (after Quarina 1943).

a type of settlement known throughout Western and Central Europe under the name of "éperon barré" or "barred spur", although the term indicates a vast and various complex of settlements protected by embankments which seem to have appeared during the early metal ages in that area (Càssola Guida 20II).

As previously said, at Meduno the defensive embankment runs for $115 \mathrm{~m}$ in length and 6-7 $\mathrm{m}$ in width. It is composed by a modest silt core and characterised, especially in the northern part, by the presence of big boulders probably gathered from the western borders of the site or the Meduna riverbed (Figure 9). The earthwork is characterised on the outside by the presence of an open conical ditch more than 2 metres deep, as recorded in the western edge (Figure Io). According to the present research, in addition to the various pottery and metal sherds of 


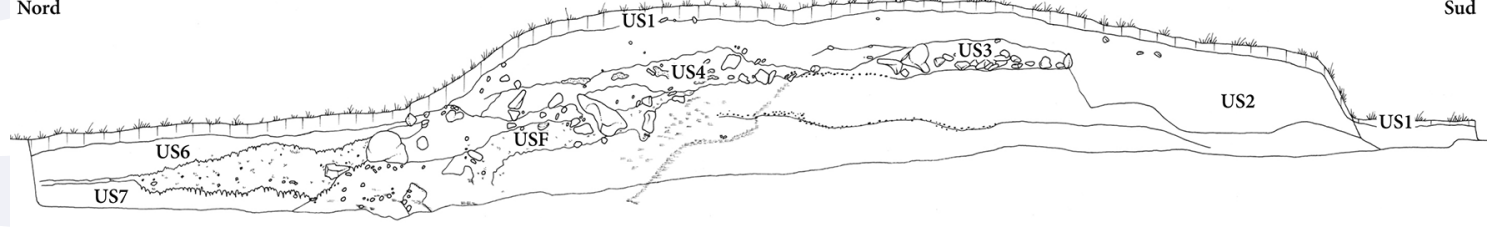

Figure 9. Meduno, Sach di Sotto. Section N-S of the embankment and the ditch (after Visentini et al. 2015).

recent age and attributable to a series of interventions to farm the embankment and plant trees, the only element surely belonging to the most recent prehistoric times can be ascribed to an advanced phase of the Ancient Bronze Age. It is a sherd of a vessel with a tongue-like handle and a central impression, found in the southern part of the defensive structure in a fragmentary stratigraphic unit.

The defensive embankment was probably built and used in a prehistoric period corresponding to the one documented in the structures found in the southern part of the river terrace. The typological comparison of the materials demonstrates it, while the two radiocarbon dates available do not completely confirm the hypothesis: while the date of the embankment layers, although ancient, can be located between 3498 and $3096 \mathrm{BC}\left(\mathrm{cal}_{2} \sigma\right)^{\mathrm{x}}$, and it is pretty close to that of the structures dug in the southern part of the terrace, the date obtained from a coal ore found in a layer of the ditch outside the embankment is located between 4038 and 3793 $\mathrm{BC}(\mathrm{cal} 2 \sigma)^{2}$, that is to say a period corresponding in Friuli to a Late Neolithic phase, which has not been observed in the gathered archaeological materials.

Little can be said about the structures inside the settlement. The coring activity systematically carried out throughout the river terrace and some test pits signalled a series of structures con-

I Unless otherwise noted, all the dates are indicated in radiometric calibrated chronology, calculated with OxCal version 4.3 following the INTCAL 13 curve and selecting the intervals with 2 sigma. Em-

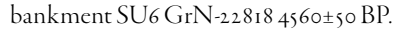

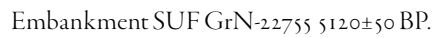

centrated only at the south-eastern border of the area, where, as previously said, pits and trenches have been found. Only few dozens of centimetres of those structures were preserved because of the farming activity and the strong washing away of the terrain surface.

From a chrono-cultural point of view, because of the scarce number of archaeological materials found in the structures and the heavy fragmentation, the interpretative analysis is quite limited. The lithic industry on chipped flint is characterised by scarcely laminated materials and the use of lithotypes mostly of local origin, being those two aspects already observed in other sites ascribable to the first metal ages in Friuli (Castiglioni et al. 2003) and generally in Northern Italy (Barfield 200I). Despite the restricted number of retouched artefacts, in the technological structure there is a prevalence of flat retouched tools and substratum. Generally, some typologies reproduce the Eneolithic ones known in Northern Italy and those of the Beaker facies, such as segments, triangular and tanged arrowheads and dagger blades, unfortunately preserved only in their mesial portion. As for the data concerning the polished-stone industry, the artefact belonging to the axe-hammer typology has been made with raw materials of local origin, while the other axe sherd, after a petrographic analysis, shows that the Eneolithic groups were interested in the raw material sources generally located in Central Europe.

The pottery production allows us make some observation on the site from a cultural point of view: such evaluations generally sup- 


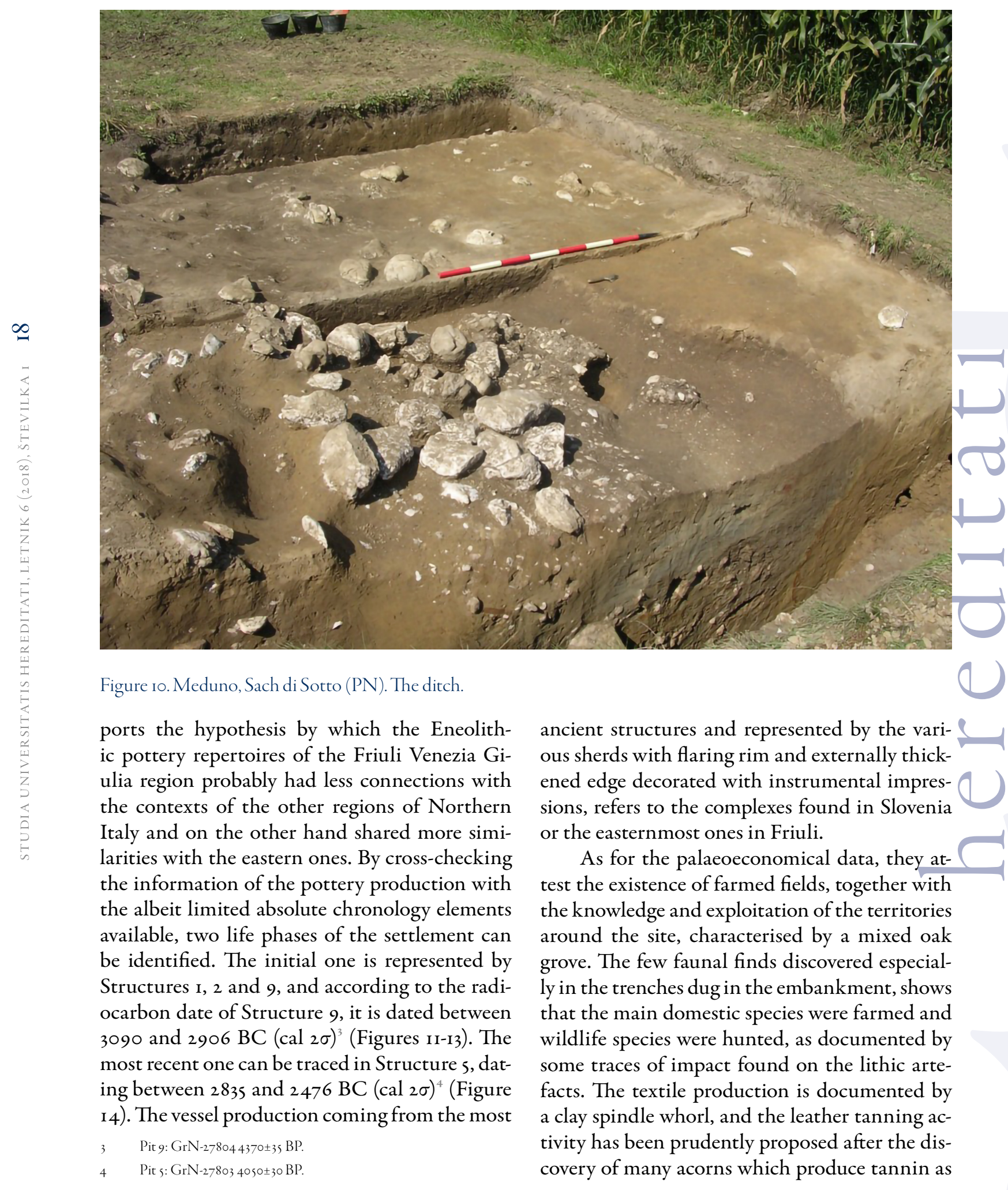




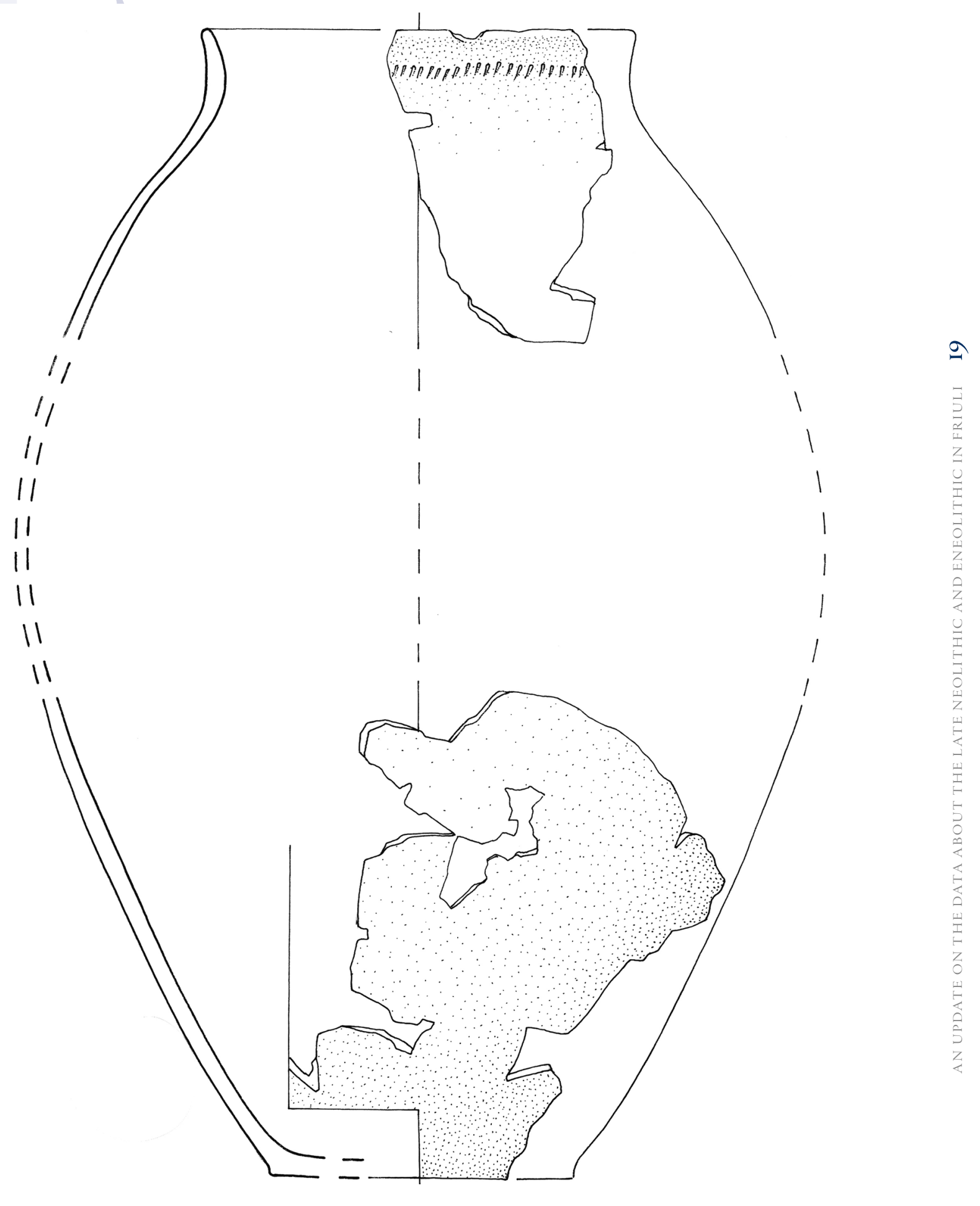

Figure rr. Meduno, Sach di Sotto (PN). A reconstructed pot from Pit 9 (after Visentini et al. 20I5, scale I:2). 

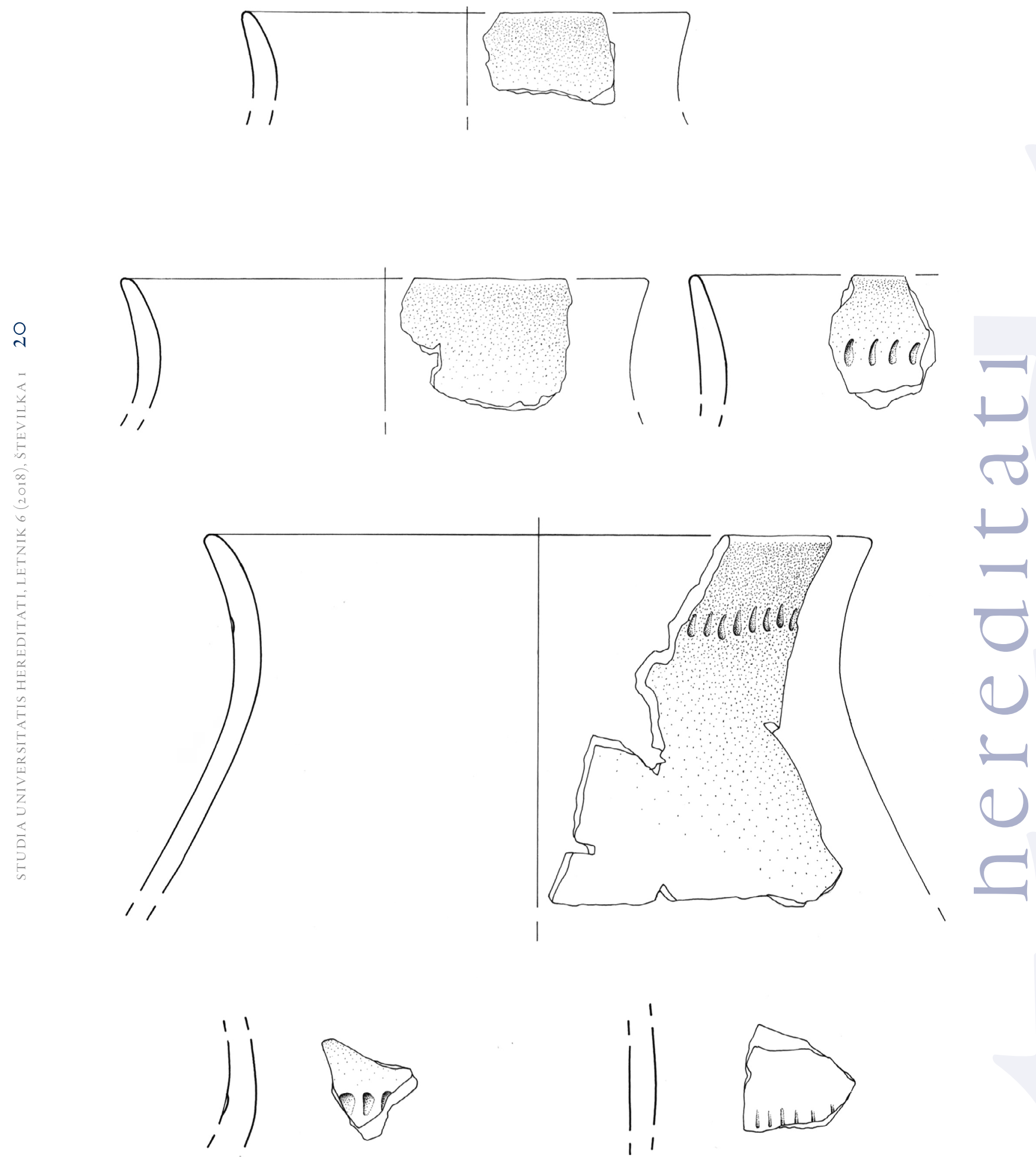

Figure 12. Meduno, Sach di Sotto (PN). Pottery from Pit 9 (after Visentini et al. 2015, scale 2:3). 

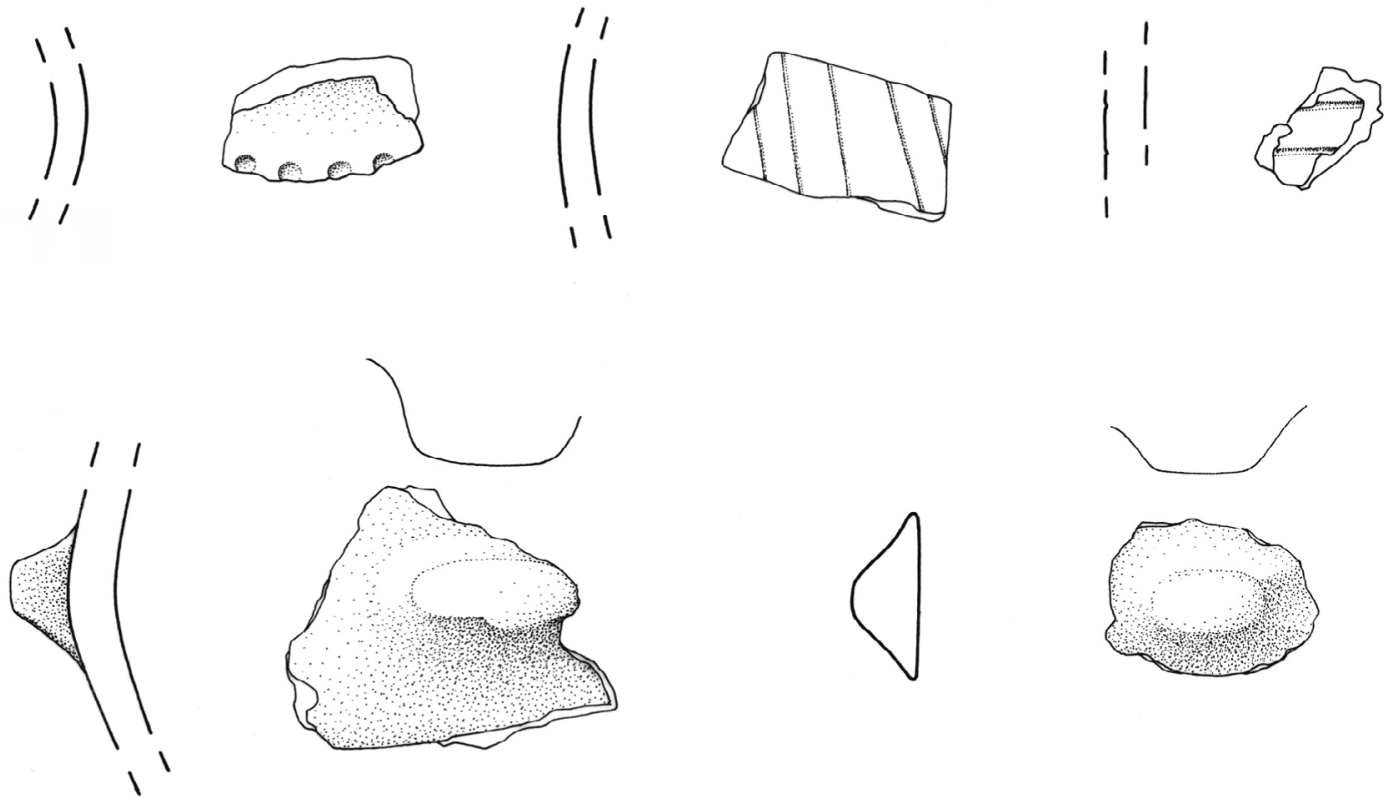

Figure 13. Meduno, Sach di Sotto (PN). Pottery from Pit 9 (after Visentini et al. 2015, scale 2:3).

a by-product if they are correctly processed, and the presence of signs of wear on some lithic artefacts due to said activity.

Little can be said about the funerary evidence of that period. They exclusively come from a cave in eastern Friuli, Ciodar des Paganis, where a human metacarpal was found and then lost (Feruglio 1916), two pendants, one made of sandstone and the other serpentine, a pierced canid tooth, a small pearl of calcarenite and a polished stone axe. Those materials suggests that the cave was used as a sepulchre between the Eneolithic and the Bronze Age (Bressan 1982), as doc- umented in similar contexts in the Italian Prealps.

In conclusion, the overview of the materials found out of context, despite their uncertain chrono-cultural ascription and functional context, significantly expands the Eneolithic occupation area in Friuli. An example is represented by the chipped flint elements, such as the various lunates and dagger blades sporadically found especially in the Friulian lowlands (Montagnari Kokelj 1990).

Furthermore, the limited lithic complexes found at Norgaredo al Torre, San Tomé di Dardago, Anaret, Molin Nuovo, Ponte San 

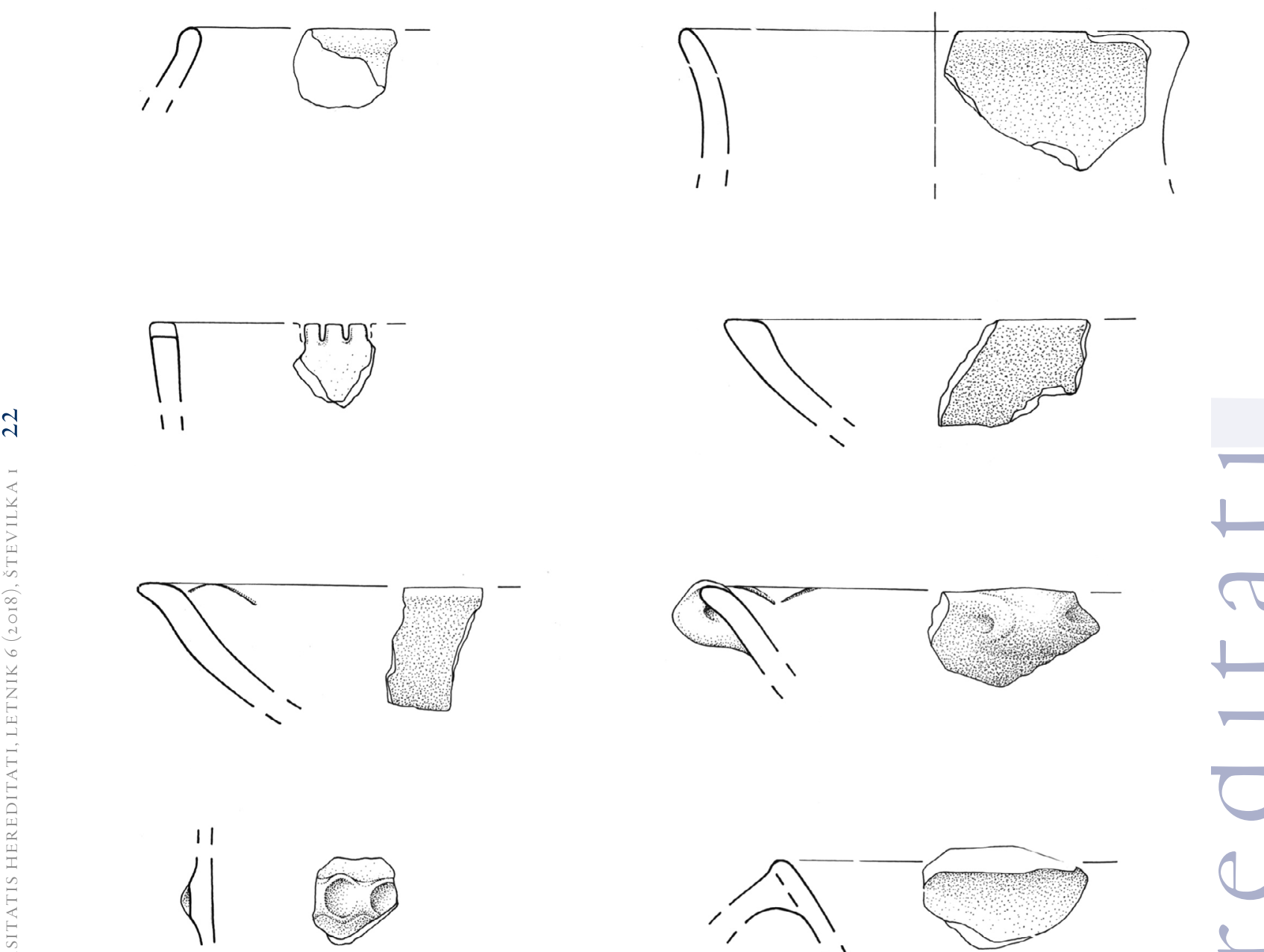

11
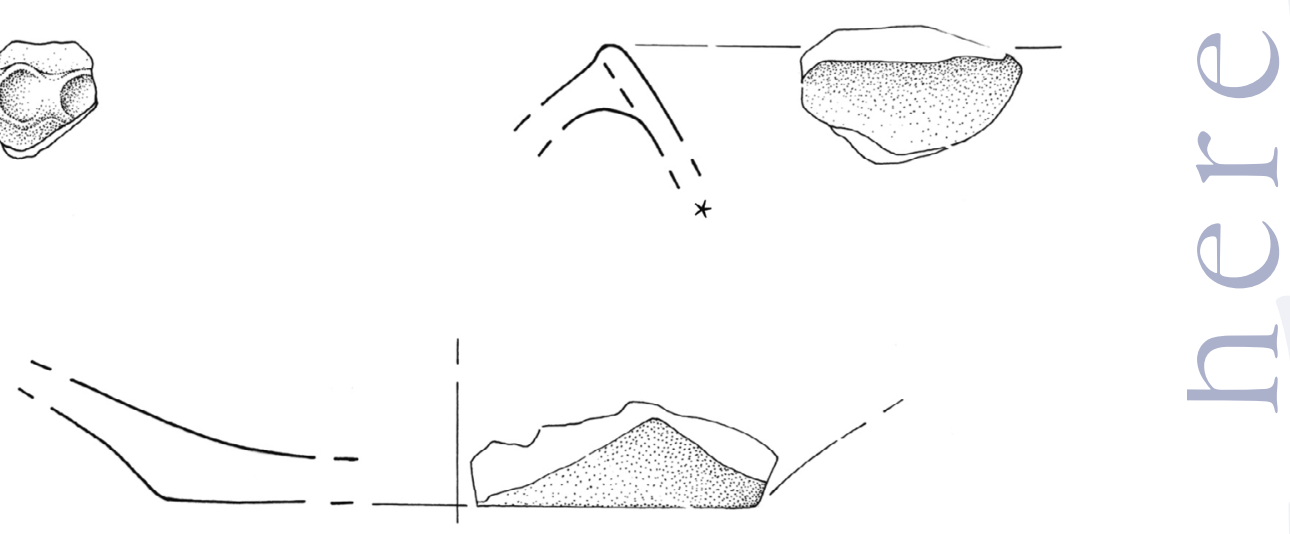

Figure I4. Meduno, Sach di Sotto (PN). Pottery from Pit 5 (after Visentini et al. 20I5, scale 2:3).

Quirino and Gramogliano, such as those found during the excavation works at Meduno, and Carpeneto, provide the framework to the structure of the lithic industry in that period. A vast use of local raw materials has been observed; sometimes the silicate limestone was used to produce summarily retouched instruments, as is the case of Anaret in the province of Pordenone, Gramogliano and Molin Nuovo in the province of Udine. The production of flakes and large flakes seems to have been the main goal of the lithic industry at those sites. The cores are main- 

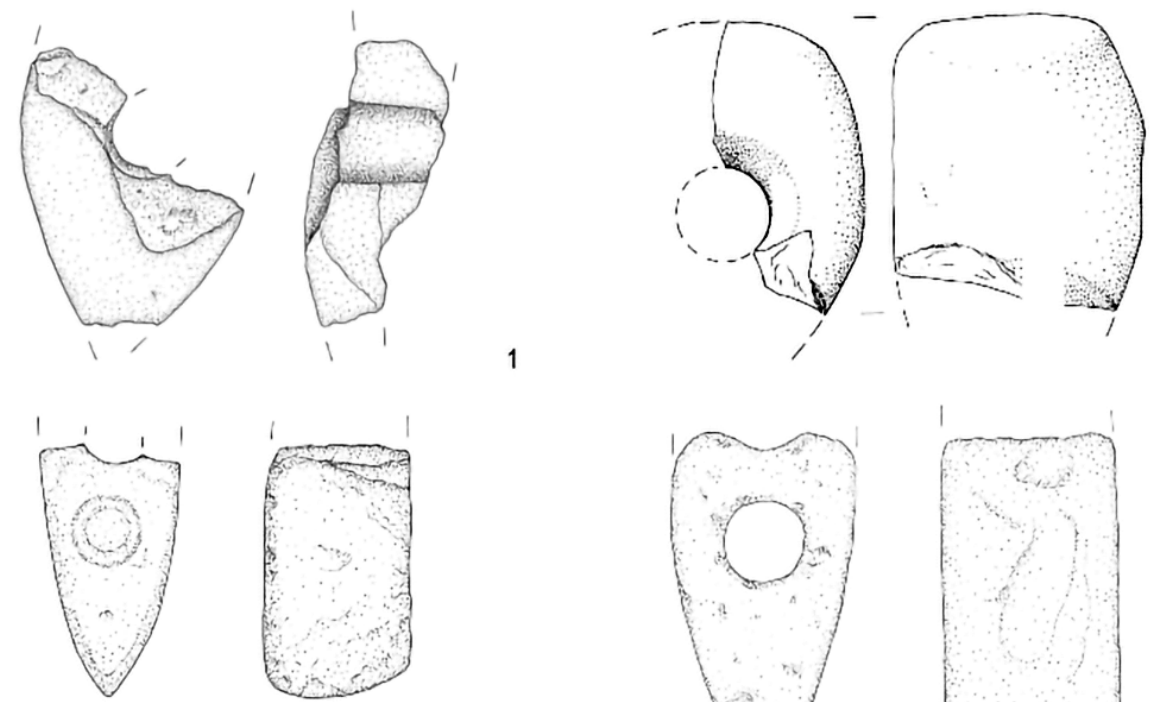

3
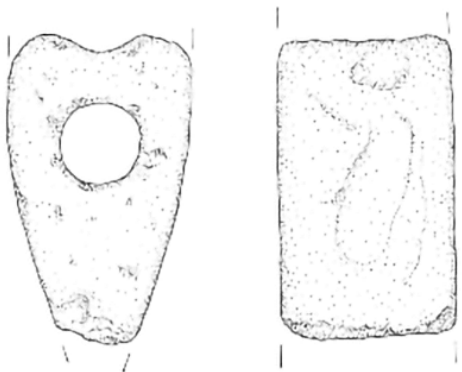

2
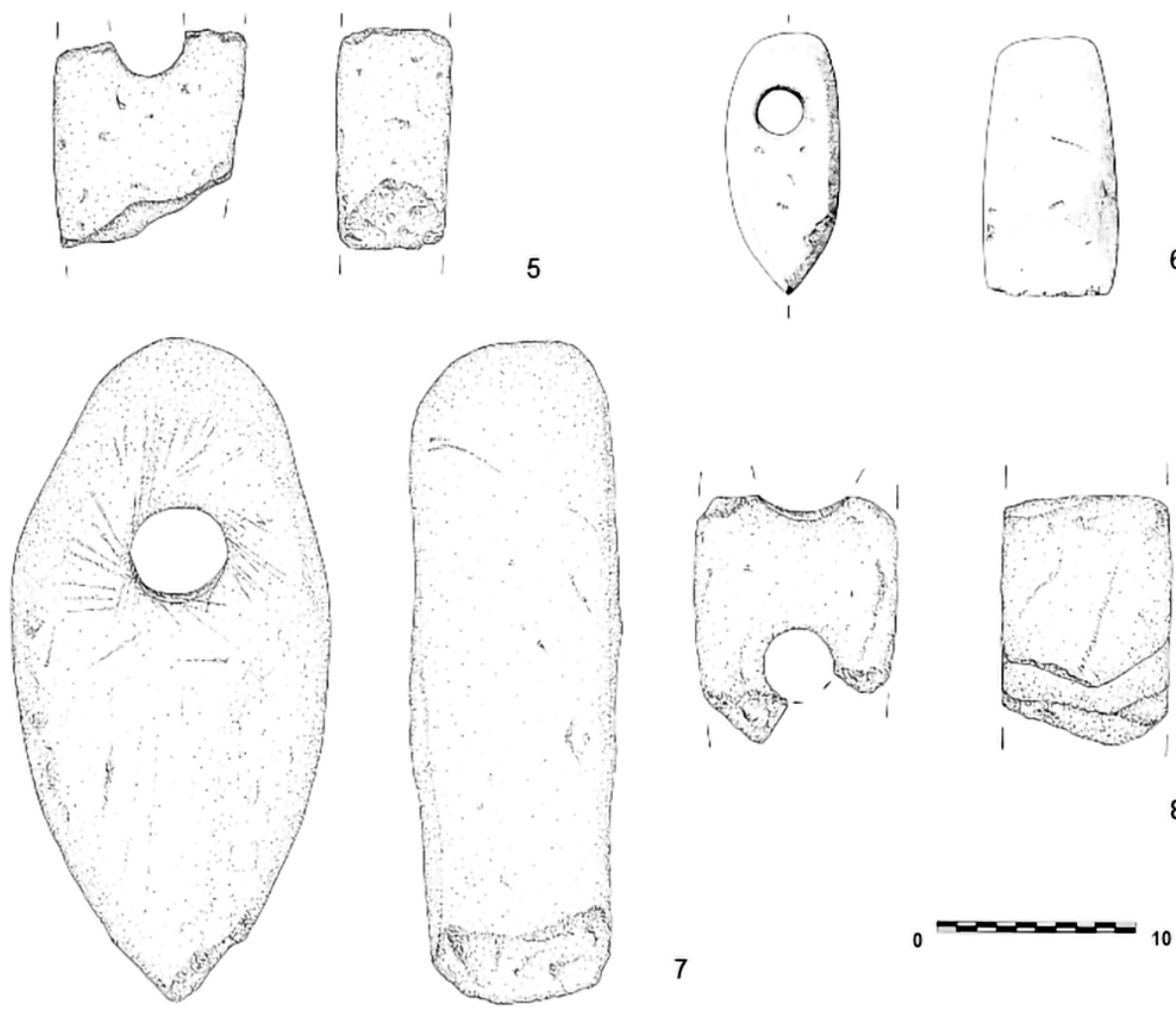

8

7

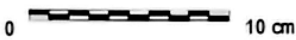

Figure 15. Polished stone shaft-hole axes: I. San Tomè, Dardago (PN), 2. Meduno, Sach di Sotto (PN), 3. Gradisca, Provesano (PN), 4. Fagagna, Torrente Lavia (UD), 5. Rive d'Arcano (UD), 6. S. Eliseo, Caporiacco (UD), 7. Colloredo di Montalbano (UD), 8. Sammardenchia, Pozzuolo del Friuli (UD). 

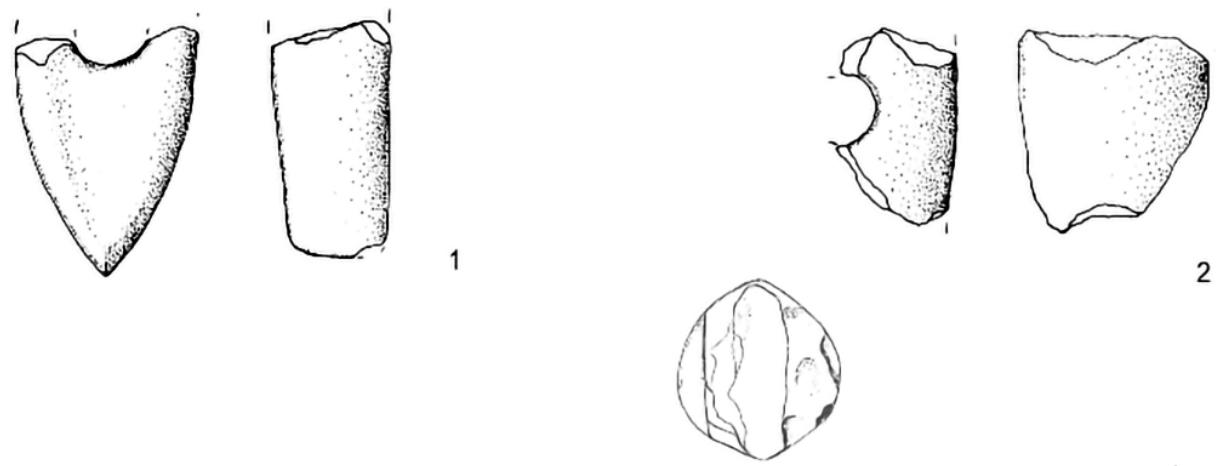

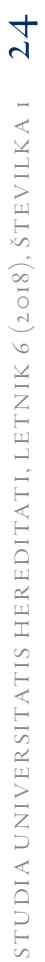
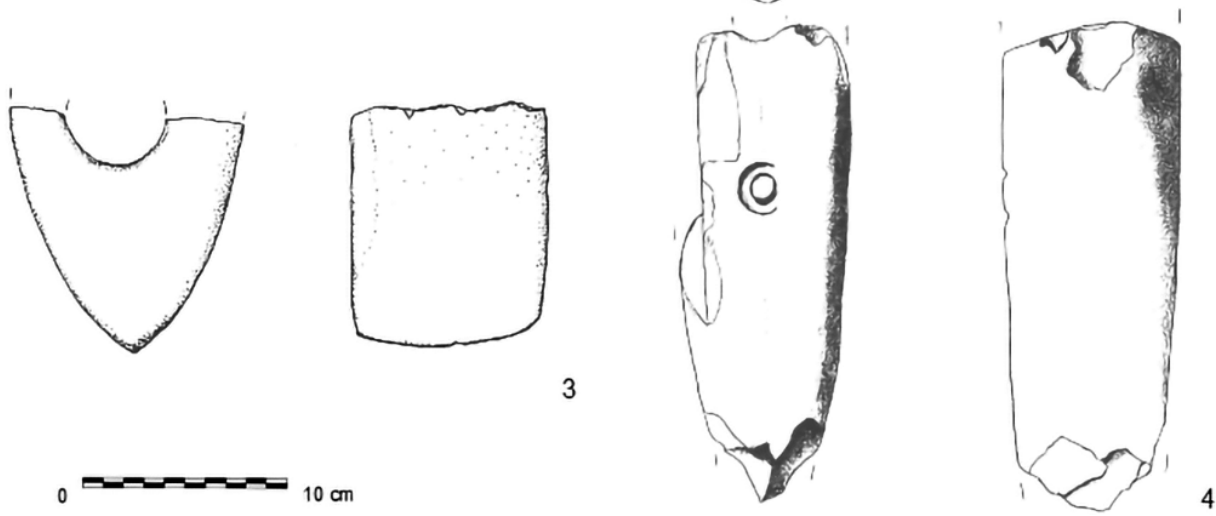

운

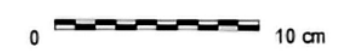

3
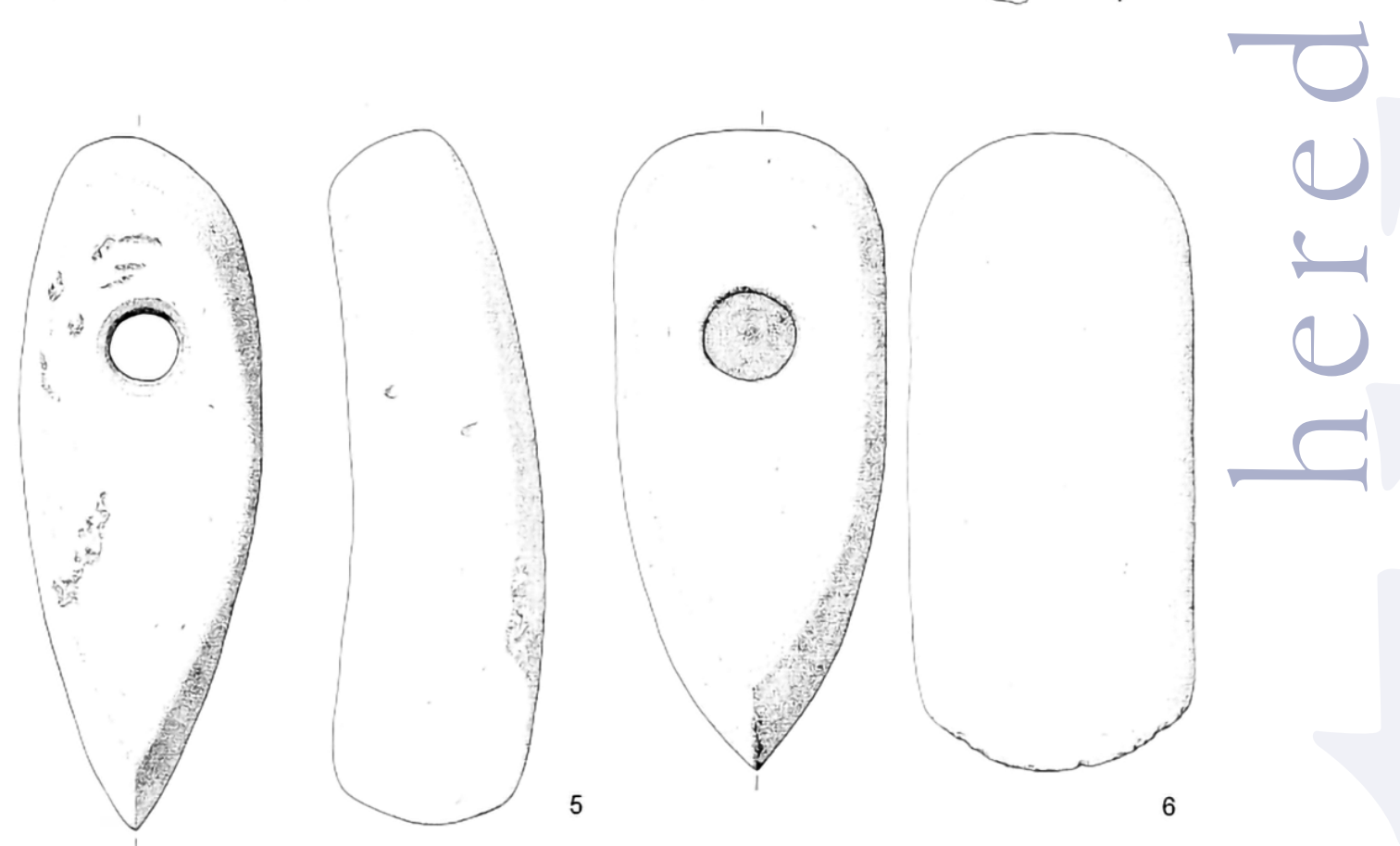

Figure 16. Polished stone shaft-hole axes: I and 2. Cjastelar, San Giovanni di Casarsa (PN), 3 and 4. San Giovanni di Casarsa (PN), 5 and 6. Roveredo, Varmo (UD). 


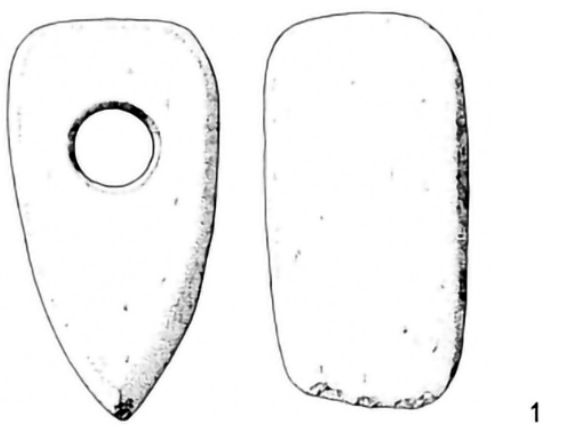

0 व $10 \mathrm{~cm}$
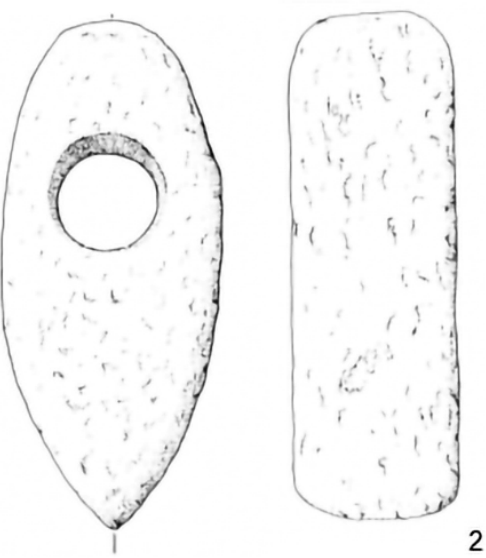

2 ก
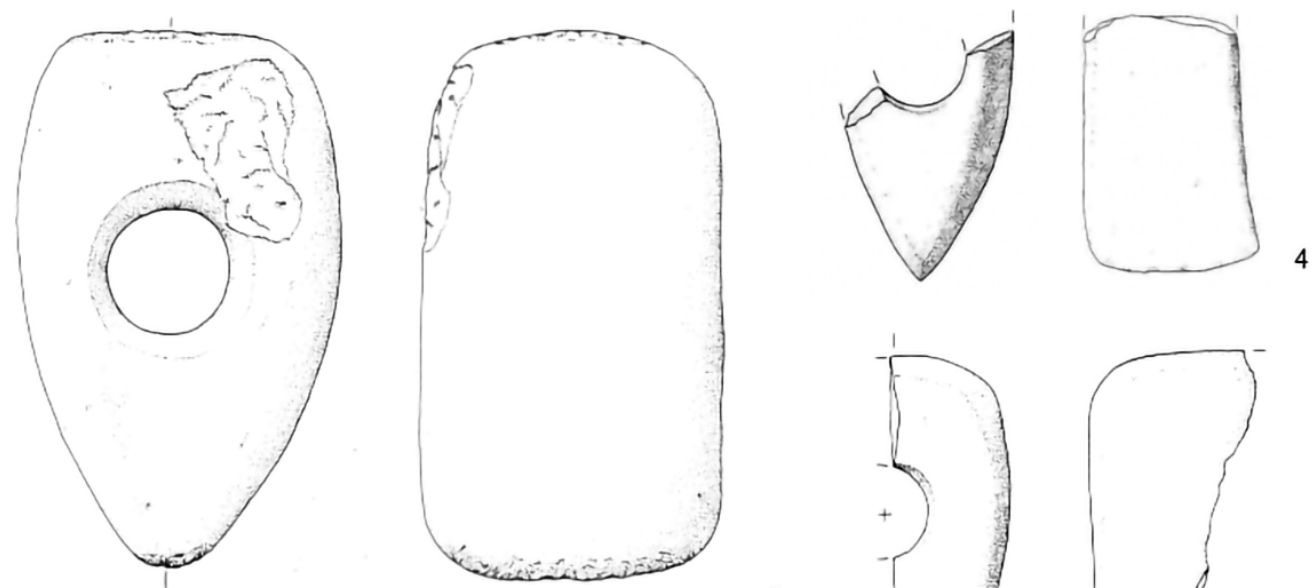

3
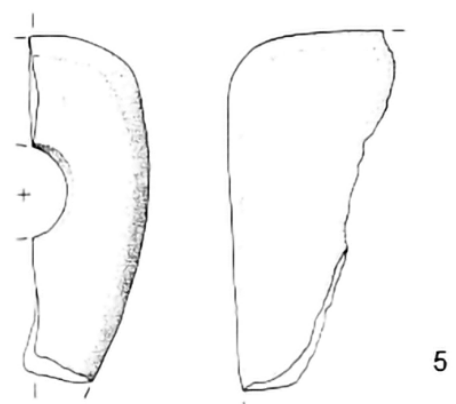

Figure 17. Polished stone shaft-hole axes: ı. Torsa (UD), 2. Pavia di Udine, 3 Aquileia (UD), 4. Castions (UD), Baldasseria (UD).

ly polyhedral with flakes and they were usually intensively exploited. The blade production is mainly documented at Meduno, where there are the secondary products for the use of blade cores and most of the instruments were created on laminar supports.

As for the polished stone, in the region more than 30 axe-hammers have been found, 2I of which in the provinces of Udine and Porde- none $e^{5}$ Some of those artefacts call attention to the presence of this typology of artefacts in settlements on high grounds which later became castellieri sites. That is the case of the castelliere of Casarsa (PN) where in addition to a lithic industry ascribable to the Eneolithic, four sherds

The morphological features and recent archaeometric studies concerning the polished stone axe found near Castions di Strada testify long-distance connection systems covering all Central Europe and dating back to the 5 th millennium BC (Bernardini et al. 2012). 

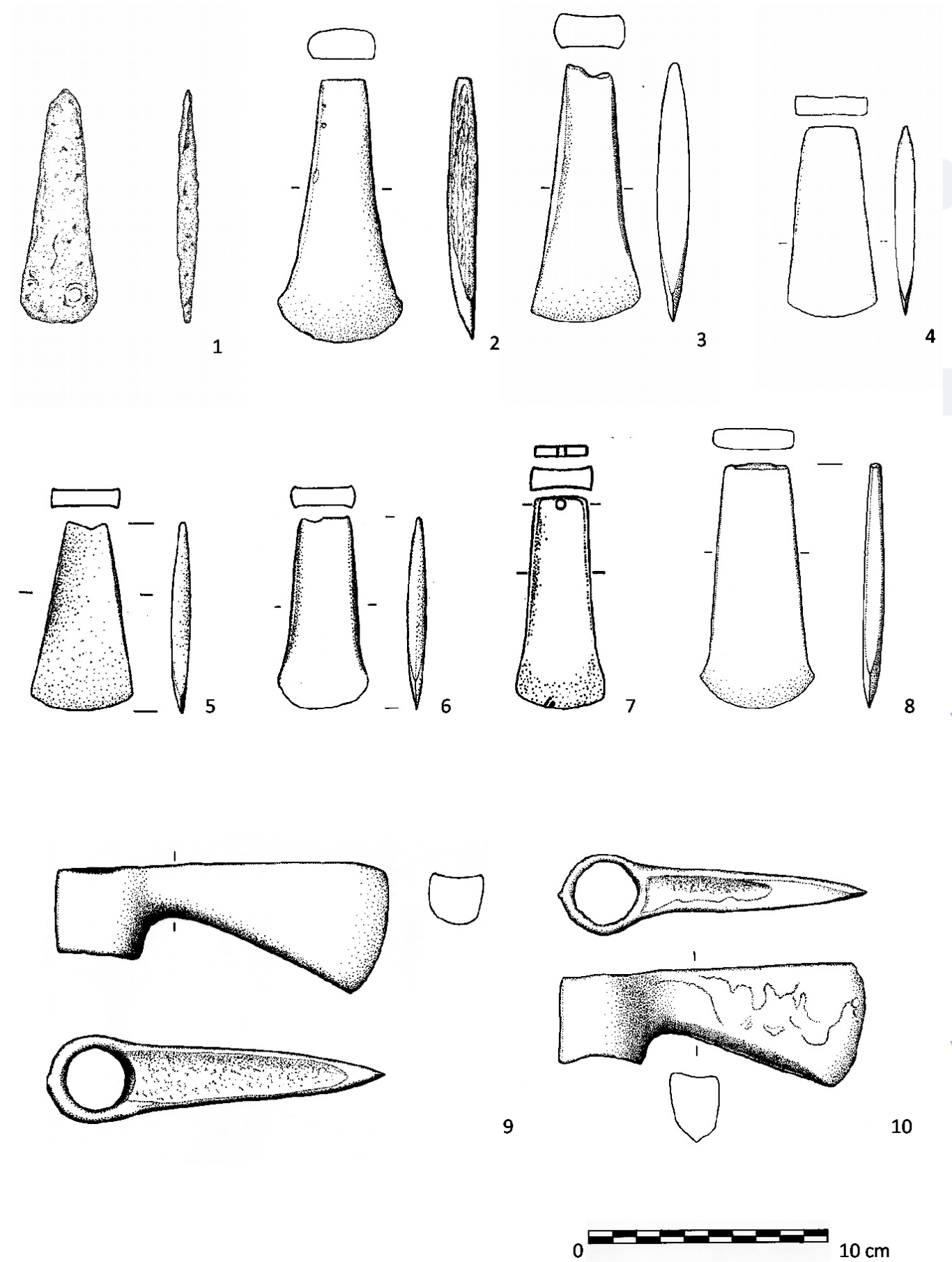

Figure 18. Copper axes: I. Sterpo of Bertiolo 2. Škocjan / S. Canziano, Tominčeva jama / Grotta Tominz, 3, 8, 9."Aquileia”; 7. Aquileia, loc. Monastero; 4. Gabrovizza di Savogna; 5 . Muina di Ovaro; 6. S. Giovanni di Casarsa, loc. Sedulis; Io. S. Daniele, loc. Fornace (n. I drawing D. De Tina, nn. 2, 3, 6, 8, 9, Io drawings G. Tasca; nn. 4-5: Giumlia Mair 2006 : figg. I-2; n. 7: Vitri 2004: fig. 6/2). 


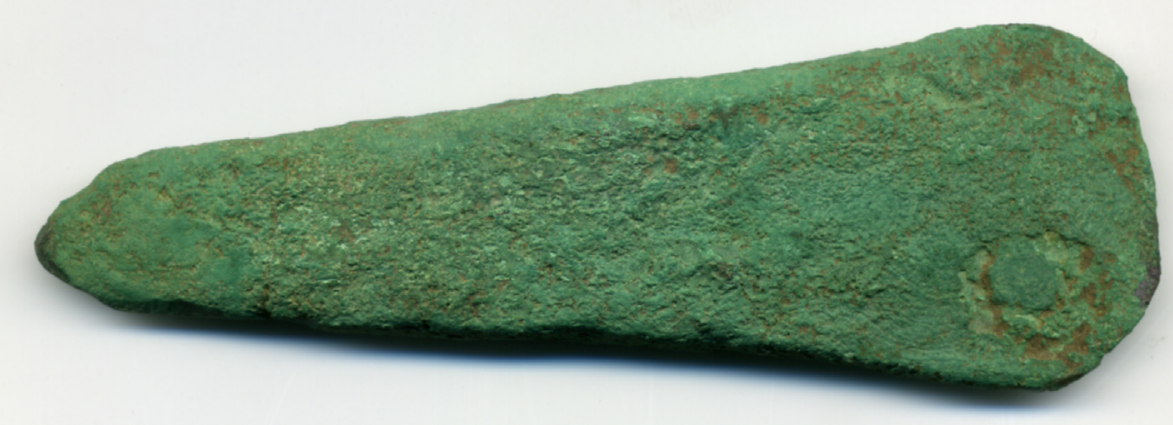

Figure 19. Copper axe from Sterpo of Bertiolo (UD) (Archaeological Museum of Udine).

of pierced axes have been found (Corazza et al. 2006), the castelliere of Gradisca sul Cosa, and most of all the already described castelliere of Meduno-Sach di Sotto (Visentini et al. 2015).

On many of those finds a preliminary lithological analysis has been conducted by observation with stereomicroscope and in diffractometry, which showed especially the use of serpentinites, highly diffused rocks, even on a regional level, as the interest for HP metaphiolites, diffused in the Neolithic context was probably decreased (D'Amico et al. 1996). The collected data on polished stone Copper Age shafthole axes suggest a change in the raw material procurement strategies to the exploitation also of local or medium-distant raw material sources, often testifying to new directions of contacts (Figures 15-17).

In conclusion, there are around ten copper axes ${ }^{6}$, often the results of old finds which were not documented, coming from a vast area between the lowlands, with a particular concentration in the area of Aquileia, and central Carnia (Tasca and Visentini 2010). It is a series of flat

6 An addition to the set could be represented by the flat trapezoidal axe of ca. I0X3,2XI cm recently donated to the Archaeological Museum of Udine by Aldo Macor, to whom we hereby express our gratitude, and sporadically found at Sterpo of Bertiolo. axes and some Kozarac-type axes, vastly diffused in Austria and generally in Eastern Europe. The analyses (XRF and SEM/EDS) conducted by A. Giumlia-Mair (2006) on three artefacts from Carnia (Muina di Ovaro), the right bank of the Tagliamento river (Sedulis di S. Giovanni di Casarsa) and the area of Cividale (Gabrovizza di Savogna), determined the intentional presence of elements in traces similar to those known in deposits in the Austrian area or in the Slovenian Styria, implicating some relations with the northern and eastern side of the Alps, and especially the area of Salzburg, one of the main districts for the extraction of copper (Figures I8-19).

\section{Conclusions}

As previously said, in the recent years an increase in the data on the late Neolithic and Eneolithic phases in Friuli allowed us to update our knowledge about that period, even though we cannot draw an organic picture yet.

In Friuli and throughout Italy, the Late Neolithic brought a loss in the cultural identity, specifically in terms of territory, consistency and solidity, which characterised the Middle and Recent Neolithic. That is particularly evident in the pottery repertoire, where the differences on a ter- 
ritorial base seems to be less clear than how they were described in the past (Visentini 2006). On the other hand, now a common matrix crucially emerges; it can be recognised by the presence of especially coarse ware pottery characterised by plastic decorations such as fingertipped ribs, conical and hollow bosses, on which Western and Padan elements have been added (Visentini 2018).

As for the Eneolithic, relevant traces of relations with the transalpine world, and especially the Balkans, can be found by looking at the raw materials which were used and the typological similarities of the pottery and metallic artefacts. In that phase, the formation of settlements defended by embankments which later found their peak in terms of diffusion during the Middle Bronze Age, suggests that they were used as a shelter because of a general situation characterised by uncertainty, or to control the surrounding territory or a route.

Translated by Elena Modotto

\section{Povzetek}

V zadnjih nekaj letih nam je ponovno preučevanje starih najdb, med njimi nekaj priložnostnih odkritij in iz nedavnih izkopavanj omogočilo, da smo posodobili svoje znanje o najbolj poznih fazah neolitika in eneolitika v Furlaniji. Distribucija najdb kaže na skoraj popolno odsotnost dokazov funerarnega značaja in območje poselitve, omejeno na višje ležečo ravnino in območje Piemonta, čeprav veliko najdb, odkritih sicer izven konteksta, izkazuje veliko širšo prostorsko razprostranjenost. Trenutno se podatki o paleoekonomskih in okoljskih vidikih poznega neolitika v Furlaniji analizirajo na osnovi preučevanja najdišča Palù di Livenze (LN), arheološko najdišče, ki ponuja zanimive podatke tudi v smislu kulturne pripadnosti najdb. Med izdelki iz gline so značilne posode grobe zrnavosti - redko so srednje zrnavosti - in okrašene skoraj izključno s plastičnimi okrasi. Odkritih je bilo zelo malo posod s štirimi izlivi; elementi t.i. zahodne tradicije so redki. Vrezani okrasi so redki, če že ne skoraj popolnoma odsotni. Kar zadeva kamnito industrijo lahko rečemo, da preskrbovalni sistemi, zlasti v Palù di Livenza, kažejo razširjenost uporabe surovin, ki prihajajo iz pokrajine Belluno in iz doline Tilmenta, medtem ko samo $40 \%$ kremena prihaja iz pod- ročja Piattaforma Veneta. Tehnološki vidiki so ostali skoraj nespremenjeni v primerjavi s tistimi, ki so bili poudarjeni v tretjem SMP slogu, pri čemer je bila varianta, ki je nastala zaradi vzpona laminarne proizvodnje, verjetno posledica povezav z zahodnim svetom, kar se opazi tudi v proizvodnji keramike.

Kar zadeva eneolitik, pa razpoložljivi podatki večinoma prihajajo iz najdišča Meduno - Sach di Sotto (PN), ki se nahaja na rečni terasi ob sotočju dveh rek. Lokacijo odlikujejo strma pobočja proti severovzhodu in jugozahodu, na severu pa je obdan z nasipom in z zunanjim obodnim jarkom. Ta vrsta naselbine je v zahodni in srednji Evropi poznana pod imenom »éperon barré« ali »barred spur $\ll$.Za kamnito industrijo odbitkovnih orodij so značilni redko laminirani primerki in uporaba litotipov, večinoma lokalnega izvora. Ti značilnosti sta. bili opaženi tudi na drugih najdiščih in se lahko pripišejo začetkom kovinskih obdobij v Furlaniji in na splošno v severni Italiji. Na splošno nekatere tipologije reproducirajo eneolitske trende, znane v severni Italiji in v fazah zvončastih čaš, kot so krožni segmenti, trikotne in ostale puščične konice ter različna rezila. Lončarska proizvodnja podpira hipotezo, da so eneolitski keramični repertoarji iz dežele Furlanije-Julijske krajine najverjetneje imeli manj povezani z drugimi območji severne Italije; več podobnosti se kaže z lončarsko produkcijo območij na vzhodu. Z navzkrižnim preverjanjem informacij o proizvodnji keramike z razpoložljivimi absolutno kronološkimi podatki, ki so na voljo, je mogoče identificirati dve fazi poselitve. Prva, zastopana s strukturami I, 2 in 9, sodi glede na radiokarbonski datum iz

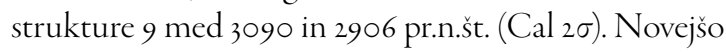
pa je mogoče zaslediti v strukturi 5 , ki sega od 2835 do 2476 pr.n.št. (Cal $2 \sigma)$.

Za zaključek lahko ugotovimo, da gradivo, ki je bilo odkrito izven konteksta, kljub negotovi kronološko-kulturni umestitvi in funkcionalnemu kontekstu, bistveno razširi eneolitsko poselitveno območje v Furlaniji. To so razni kremenasti odbitki, kot so npr. noži, bakrene in polirane kamnite sekire.

\section{Summary}

In the last years, the re-examination of old finds, some casual discoveries and recent excavation works allowed us to update our knowledge on the latest phases of the Neolithic and Eneolithic in Friuli. The distribution 
of the finds shows an almost total absence of funerary evidences and the occupation zone limited to the upper plain and the piedmont area, although many finds found out of context had a much wider diffusion over the territory.

At the moment, the data of the palaeoeconomical and environmental aspects concerning the Late Neolithic in Friuli, are being analysed through the study of the site of Palù di Livenza (PN), a site which provides interesting data also in terms of cultural materials. The clay production is characterised by vessels with coarse ware rarely medium ware - and almost exclusively plastic decorations. There are few four-spouted vessels and the elements of Western tradition are rare. Incised decorations are scarce if not completely absent. As for the lithic industry, the provision systems, especially at Palù di Liven$\mathrm{za}$, show the prevalence of raw materials coming from the province of Belluno and the Tagliamento's valleys, whilst only $40 \%$ of flint comes from the Piattaforma Veneta. The technological aspects remained almost unvaried as compared to those highlighted in the third SMP style, with a variant constituted by the rise in the laminar production probably due to the connections with the Western world, which have been observed also in the ceramic production.

As for the Eneolithic, the available data mostly come from Meduno - Sach di Sotto (PN), a site locate on a fluvial terrace at the confluence of two rivers. It is characterised by steep slopes to the North-East and SouthWest, and it is defended to the North by an embankment with an external ditch. This type of settlement is well-known in Western and Central Europe under the name of "éperon barré" or "barred spur". The lithic industry on chipped flint is characterised by scarcely laminated materials and the use of lithotypes mostly of local origin, being those two aspects already observed in other sites ascribable to the first metal ages in Friuli, and generally in Northern Italy. Generally, some typologies reproduce the Eneolithic ones known in Northern Italy and those of the Beaker facies, such as segments, triangular and tanged arrowheads and dagger blades. The pottery production supports the hypothesis by which the Eneolithic ceramic repertoires of the Friuli Venezia Giulia region probably had less connections with the contexts of the other regions of Northern Italy and on the other hand shared more similarities with the eastern ones. By cross-checking the information of the ceramic production with the albeit limited absolute chronology elements available, two life phases of the settlement can be identified. The initial one is represented by Structures I, 2 and 9 , and according to the radiocarbon date of Structure 9, it dates between 3090 and 2906 BC ( $\mathrm{cal} 2 \sigma)$. A more recent one can be traced in Structure 5, dating between 2835 and $2476 \mathrm{BC}$ ( $\mathrm{cal} 2 \sigma)$.

In conclusion, materials found out of context, despite their uncertain chrono-cultural ascription and functional context, significantly expands the Eneolithic occupation area in Friuli. Those are chipped flint elements, such as the various reports of lunates and dagger blades, the copper and polished stone axes.

\section{Bibliography}

Barfield, L. H. 1999. "The Moser collection in the Naturhistorisches museum, Vienna."

Atti della Società per la Preistoria e Protostoria della Regione Friuli-Venezia Giulia XI: 19-62.

Barfield, L. 200I. "Beaker Lithics in Northern Italy." In Bell Beakers today: pottery, people, culture, symbols in prehistoric Europe, edited by F. Nicolis, 507-I8. Proceedings of the International colloquium, Riva del Garda (Trento, Italy), II-I6 May 1998. Trento: Provincia autonoma di Trento, Servizio beniculturali, Ufficcio beni archeologici.

Bastiani, G., A. Fontana, A. Fragiacomo, and A. Pessina 1997. "Presenze preistoriche di superficie a Gramogliano (Corno di Rosazzo, Udine)." Quaderni Friulani di Archeologia VII: I7-4I.

Bernardini, F., D. De Min, P. Lenaz, C. Šida, C. Tuniz, and M. Montagnari Kokelj. 2012. "Shaft-Hole Axes from Caput Adriae Made from Amphibole-Rich Metabasites: Evidence of Connections between Northeastern Italy and Central Europe during the Fifth Millennium BC.” Archaeometry 54, 3 (2OI2): 427-4I.

Bertoldi, F. 1996. "Il riparo di Monrupino nel Carso Triestino." Atti della Società per la 
Preistoria e Protostoria della Regione FriuliVenezia Giulia IX: 137-70.

Bianchin Citton, E., C. Conci, N. Dal Santo, S. Ferrari, E. Mottes, P. Salzani, P. Visentini, and S. Ziggiotti. (in press). "Approccio tecno-tipologico e funzionale ai complessi litici datati tra la metà del $\mathrm{V}$ millennio e la metà del IV millennio a.C. di Friuli, Veneto, Trentino." In Atti del Convegno Vasi a bocca quadrata Evoluzione delle conoscenze, nuovi approcci interpretativi, edited by E. Mottes. Soprintendenza per i beni librari, archivistici e archeologici, Riva del Garda, 13-I5 maggio 2009. Trento: Provincia autonoma di Trento.

Borgna, E., P. Càssola Guida, S. Corazza, G. Simeoni, P. Visentini, and S. Vitri 201 I. "Aspetti e problemi dell'età del rame nelle regioni altoadriatiche dal Friuli al Carso." In L'età del rame in Italia, in memoria di Gianni Balio Modesti), 59-67. Atti della XXXVIII Riunione Scientifca dell'IIPP (Bologna, 26. - 29.novembre 2008). Firenze: Instituto Italiano di preistoria e protostoria.

Bressan, F. 1982. "Il Ciondar des Paganis (Faedis, Udine)." Preistoria Alpina I8: III20.

Càssola Guida, P. 20rr. "Un tipo peculiare di fortificazione lo "sperone sbarrato". In $D i$ terra e di ghiaia. La protostoria del Medio Friuli tra Europa e Adriatico, edited by G. Simeoni and S. Corazza, 16I-67. Mereto di Tomba: La Grame.

Castiglioni, E., A. Fontana, and P. Visentini. 2003. "Recenti dati sulla preistoria del Friuli occidentale." In Giornata di studio sull'archeologia del medio e basso Tagliamento "in ricordo di Giuseppe Cordenos”, edited by G. Tasca, I0-35. San Vito al Tagliamento, antico Ospedale dei Battuti, I 4 marzo 1999. Pordenone: Comune di San Vito al Tagliamento. Corazza, S., G. Tasca, and P. Visentini. 2006.

"Nuovi materiali da Casarsa della Delizia (Pordenone).” In Atti del Convegno
Preistoria dell'Italia Settentrionale. Studi in ricordo di Bernardino Bagolini (Udine, Settembre 2005), edited by A. Pessina and P. Visentini, 573-78. Pubblicazioni Varie del Museo Friuliano di Storia Naturale 53. Udine: Edizioni del Museo Friuliano di Storia Naturale.

D'Amico, C., M. Ghedini, R. Micheli, and E. Montagnari Kokelj. 1996. "Le Asce Forate del Friuli-Venezia Giulia." In "Le Vie della Pietra Verde, L'Industria Litica Levigata nella Preistoria dell'Italia Settentrionale" edited by M. Venturino Gambari, 22938. Exhibition catalogue (Torino-Alba, september-december 1996). Torino.

Dal Santo, N. 2003. "Provenienza e utilizzo delle rocce silicee scheggiate del sito neolitico di Palù di Livenza (Pordenone). Atti della Società per la Preistoria e Protostoria del Friuli-Venezia Giulia XIV: IO3-48.

Feruglio, E. 1916. "Il “Ciondar des Paganis" • stazione neolitica presso Faedis (Prealpi Giulie)." Mondo sotterraneo XII, I-3: 37-48.

Fragiacomo, A., and A. Pessina. 1995. "Industrie litiche da Molin Nuovo (UD) nelle collezioni dei Civici Musei di Udine." Quaderni Friulani di Archeologia V: 23-43. Gerdol, R., and G. Stacul. 1978. "Il Castelliere di Ponte S. Quirino presso Cividale.” In I castellieri di Nivize Monte Grisa Ponte S. Quirino, edited by M. Moretti, R. Gerdol and G. Stacul, 65-98. Atti dei Civici Musei di storia ed arte di Trieste. Monografie di preistoria 2. Trieste.

Gilli, E., and E. Montagnari Kokelj. 1993. "La Grotta delle Ciclami nel Carso Triestino (materiali degli scavi 1959-196I)." Atti della Società per la Preistoria e la Protostoria della Regione Friuli-Venezia Giulia VII: 65-162.

Giumlia Mair, A. 2006. "Analisi archeometallurgiche su tre asce piatte rinvenute in Friuli." In Atti del Convegno Preistoria dell'Italia Settentrionale. Studi in ricordo di Bernardino Bagolini (Udine, 
Settembre 2005), edited by A. Pessina and P. Visentini, 579-84. Pubblicazioni Varie del Museo Friuliano di Storia Naturale 53. Udine: Edizioni del Museo Friuliano di Storia Naturale.

Greif, T., and E. Montagnari Kokelj. 2002. "Venezia Giulia (North-Eastern Italy) and Central and Western Slovenia in the Late Neolithic." In Il declino del mondo neolitico. Ricerche in Italia centrosettentrionale fra aspetti peninsulari, occidentali e nord-alpini, edited by A.

Ferrari and P. Visentini, 177-86. Atti del Convegno (Pordenone, 2001). Quaderni del Museo Archeologico del Friuli Occidentale 4. Pordenone.

Legnani, F., and F. Stradi. 1963. "Gli scavi nella Caverna dei Ciclami nel Carso Triestino.” Atti della VII Riunione Scientifica dell'IIPP (Firenze, 2. - 3. febbraio 1963), 3138. Firenze: Instituto Italiano di preistoria e protostoria.

Marinelli, O. 1922. “G.B. De Gasperi. Pochi dati sui castellieri friulani.” In Scritti vari di geografia e geologia, edited by G. Dainelli, I- 28. Pubblicazione postuma, Memorie Geografiche di G. Dainelli, Firenze.

Micheli, R. (in press). "Frecce da scoccare, prede da colpire: alcune osservazioni sulle cuspidi tardoneolitiche di Palù di Livenza." In Le quistioni nostre paletnologiche piu importanti...Trent'anni di tutela e ricerca preistorica in Emilia occidentale, Parma 8-9 giugno 2017.

Montagnari Kokelj, E. 1990. "Le industrie litiche della Bassa friulana fra il III e la prima metà del II millennio A.C." Aquileia Nostra LXI: 9-28.

Neugebauer, J.-W., and C. NeugebauerMaresch. 200I. "Bell Beaker Culture in Austria." In Bell Beakers today: pottery, people, culture, symbols in prehistoric Europe, edited by F. Nicolis, 42937. Proceedings of the International colloquium, Riva del Garda (Trento,
Italy), II-I6 May 1998. Trento:

Provincia autonoma di Trento, Servizio beniculturali, Ufficcio beni archeologici.

Pedrotti, A. 1990. "L'insediamento di

Kanzianiberg: rapporti culturali fra Carinzia ed Italia settentrionale durante il Neolitico." In The Neolithisation of the Alpine Region. Atti dell'International Round Table (Brescia, I988), edited by P. Biagi, 213-26. Monografie di Natura Bresciana 13 . Brescia.

Pettarin, S., G. Tasca, and P. Visentini. 1997. "Materiali preistorici e protostorici da San Tome di Dardago (Budoia-Pordenone).” Atti della Società per la Preistoria e la Protostoria della Regione Friuli-Venezia Giulia X: I5I-95.

Quarina, L. 1943. "Castellieri e tombe a tumulo in provincia di Udine." Ce Fastu? 19, 54-86. Bollettino della S.F.F. Anno XIX/ı - 2. Aprile 1943. Udine.

Tasca, G., and P. Visentini. 20ı0. “Asce dell'età del rame in Friuli Venezia Giulia (Italia nord-orientale)." Gortania. Geologia Paleontologia Paletnologia 31: 165-72.

Tellini, A. 1900. "Descrizione geologica della Tavoletta Topografica di Udine.” In Carta geologico-agraria del podere d'istruzione del regio Istituto di udine e dintorni, edited by G. Nallino, 7-6I. Udine: R. Staz. Sperim. Agr.

Visentini, P. 2006. "Aspetti cronologici e culturali della fine del Neolitico dell'Italia nord-orientale." In Atti del Convegno Preistoria dell'Italia Settentrionale. Studi in ricordo di Bernardino Bagolini (Udine, Settembre 2005), edited by A. Pessina and P. Visentini, 225-42. Pubblicazioni Varie del Museo Friuliano di Storia Naturale 53. Udine: Edizioni del Museo Friuliano di Storia Naturale.

Visentini, P. 2018. "La fine del Neolitico nell'Italia nord-orientale. Insediamenti e produzioni tra V e IV millennio a.C. "I "The End of the Neolithic in North-Eastern Italy. Settlement and Productions between 
$5^{\text {th }}$ and $4^{\text {th }}$ Millennium BC." MILLENNI:

Studi di archaeologia preistorica, I5.

Firenze: Museo e Istituto Fiorentino di

Preistoria.

Visentini, P., R. Avigliano, E. Castiglioni,

A. Fontana, C. Lemorini, C. Mazzoli,

G. Petrucci, and G. Tasca. 2015. "Il sito

fortificato di Meduno Sach di Sotto

(Pordenone) nel quadro dell'Eneolitico

delle regioni vicine." Gortania. Geologia

Paleontologia Paletnologia 36: 69-I24.

Vitri, S. 2004. Contributi alla ricostruzione

della topografia di Aquileia preromana. In:

Aquileia dalle origini alla costituzione del

Ducato longobardo. Topografia - urbanistica

- edilizia pubblica, 39-64. Trieste:

Antichità Altoadriatiche 59.

Vitri, S., A. Balasso, and G. Simeoni. 2012.

"Tumuli e strutture abitative presso

Flaibano nell'alta pianura friulana (Italia,

Friuli Venezia Giulia) vecchi e nuovi dati." In Ancestral Landscape, edited by E.

Borgna and S. Müller Celka, 239-52. Lyon:

Maison de l'Orient et de la Méditerranée. 